\title{
QUALITY OF LIFE IN PATIENTS BEFORE AND AFTER LUMBAR SURGERY IN DIFFERENT WORK SITUATIONS
}

\author{
QUALIDADE DE VIDA DE PACIENTES ANTES E DEPOIS DE CIRURGIA LOMBAR EM \\ DIFERENTES SITUAÇÕES DE TRABALHO
}

\author{
CALIDAD DE VIDA DE LOS PACIENTES ANTES Y DESPUÉS DE CIRUGÍA \\ LUMBAR EN DIFERENTES SITUACIONES DE TRABAJO
}

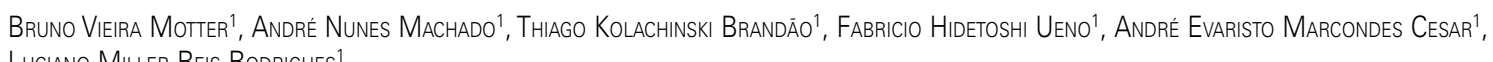
Luciano Miller Reis Rodrigues ${ }^{1}$

\begin{abstract}
Objective: To evaluate the quality of life of patients after spine surgery related to the return to work activities. Methods: Retrospective review of medical records of patients operated for degenerative spinal disease and application of questionnaire about quality of life (SF-36) in the preoperative and postoperative periods at one month, six months, one year and two years. Patients were divided into three groups: those who returned to work, who were away from work and retired patients. Then the statistical analysis was conducted and the evolution of quality of life was assessed according to the return to activity. Results: Evaluating patients for the variable return to activity, it was found statistically significant difference in the time for the variables: functional, physical, pain, vitality, social and mental. For patients who did not return to activity, the evolution was statistically significant for the variables: functional, physical, pain, vitality and social. For retired patients the outcome was statistically significant for all domains, except for "General". Conclusion: The quality of life has improved in all groups postoperatively, being observed more significant results in the group that returned to their work activities.
\end{abstract}

Keywords: Spine/surgery; Working conditions; Return to work; Quality of life.

\section{RESUMO}

Objetivo: Avaliar a qualidade de vida dos pacientes depois de cirurgia de coluna e relacionar seu retorno às atividades laborais. Método: Realizou-se avaliação retrospectiva de prontuários de pacientes operados por doença degenerativa da coluna vertebral e aplicou-se questionário sobre qualidade de vida (SF-36) no pré e pós-operatório, nos períodos de um mês, seis meses, um ano e dois anos. Os pacientes foram divididos em três grupos: que retornaram ao trabalho; que estavam afastados de suas atividades e pacientes aposentados. A seguir, realizou-se a análise estatística e a evolução da qualidade de vida foi avaliada de acordo com o retorno à atividade. Resultados: Avaliando-se os pacientes segundo a variável retorno à atividade, verificou-se diferenças estatisticamente significantes nos momentos avaliados para as variáveis: funcional, físico, dor, vitalidade, social e mental. Para os pacientes que não retornaram à atividade, a evolução foi estatisticamente significante para as variáveis: funcional, físico, dor, vitalidade e social. Nos pacientes aposentados, a evolução foi estatisticamente significante para todos os domínios, com exceção de "Geral". Conclusão: Houve melhora da qualidade de vida em todos os grupos no pós-operatório, sendo observados resultados mais expressivos no grupo que retornou às atividades laborais.

\section{Descritores: Coluna vertebral/cirurgia; Condições de trabalho; Retorno ao trabalho; Qualidade de vida.}

\section{RESUMEN}

Objetivo: Evaluar la calidad de vida de los pacientes después de la cirugía de columna y relacionar su retorno a las actividades laborales. Métodos: Se realizó una evaluación retrospectiva de las historias clínicas de los pacientes operados por enfermedad degenerativa de la columna vertebral y se aplicó el cuestionario sobre la calidad de vida (SF-36) en el preoperatorio y postoperatorio en um mes, seis meses, um año y dos años. Los pacientes fueron divididos en tres grupos: los que volvieron al trabajo, los que se alejaron de sus actividades y los pacientes jubilados. A continuación, se realizó el análisis estadístico y la evaluación de la evolución de la calidad de vida de acuerdo con el retorno a la actividad. Resultados: La evaluación de los pacientes de acuerdo a la variable de retorno a la actividad, encontró diferencia estadísticamente significativa en los momentos evaluados para las variables: funcional, física, dolor, vitalidad, social y mental. Para los pacientes que no regresaron a la actividad, la evolución fue estadísticamente significativa para las variables: funcional, física, dolor, vitalidad y social. Para los pacientes jubilados, el resultado fue estadísticamente significativo para todos los dominios, a excepción de "General". Conclusión: Hubo mejoría en la calidad de vida en todos los grupos después de la operación, observándose resultados más significativos en el grupo que volvió a sus actividades laborales.

Descriptores: Columna vertebral/cirugía; Condiciones de trabajo; Retorno al trabajo; Calidad de vida. 


\section{INTRODUCTION}

Diseases of the musculoskeletal system are the primary cause of workplace absenteeism and the second leading cause of adhesion to social security programs, ${ }^{1}$ where low back pain is responsible for $50 \%$ of all chronic musculoskeletal diseases. ${ }^{2,3}$ Epidemiological studies show that $80 \%$ of the population have either already experienced or will experience an episode of low back pain during their productive lives. ${ }^{3-7}$ Low back pain, one of the main reasons for doctor's appointments, hospitalizations and surgical interventions, usually affects men over 40 years of age and women aged between 50 and 60 years ${ }^{8,9}$ and is responsible for approximately $25 \%$ of cases of premature disability. ${ }^{8-10}$

As low back pain affects the economically active population and is related to inability to work, it entails costs resulting from loss of productivity, days off work, medical and legal charges, and the payment of insurance and disability compensation. ${ }^{11,12}$

In the last 10 years there has been an important increase in the number of surgical procedures on the spine geared towards the treatment of the different ailments that cause low back pain. There has been discussion, though without consensus, of the indications and surgical techniques used in the spine that are frequently used to treat low back pain. These are usually divided between decompression, stabilization (fusion or arthrodesis), or a combination of both techniques. ${ }^{13-15}$

Over the years, various studies have been produced relating to the impact of spinal surgery on quality of life, and to the functional changes produced by these surgeries, but there is always some uncertainty regarding the relationship between surgical outcome and patient work reintegration. However, the aim of this study was to assess the quality of life of patients after spinal surgery via the standardized protocol SF-36, and to relate their return to their work activities.

\section{METHODS}

The medical records of 111 patients operated between 2004 and 2012 at the Hospital Estadual Mário Covas were evaluated retrospectively; 51 female patients and 60 male patients between 29 and 84 years of age, with an average age of 55.9 years, who had undergone surgery for degenerative spinal disease.

A standardized questionnaire on quality of life (SF-36) was applied preoperatively and postoperatively over a period of 1 month, 6 months, 1 year and 2 years, and functional capacity, physical appearance, degree of pain, general state of health, vitality, social aspect, limitation due to emotional aspect and mental health were measured.

The operated patients were asked about their work situation in the 1-year period, and divided into three groups: The first group of patients who had returned to work, the second group of patients who were on sick leave, and the third group of patients who were already retired or had retired after the spinal surgery.

The pathologies included in this study were spinal stenosis (46.9\%), spondylolisthesis (20.7\%) and herniated intervertebral disc $(32.4 \%)$, and the surgery evaluated was decompression and arthrodesis. However, the different disorders or the degree of intraoperative difficulty were not considered.

\section{Statistical Analysis}

The results of the quality scores were described via median percentiles 25 and 75 due to the non-normality of the data. The data were analyzed using the statistical software Stata 11.0.

The progression of quality of life according to return to work was verified using the Friedman test. The repeated measures Anova test was used to analyze whether there was any change in the quality of life scores according to return to work (yes, no and retired). The $\mathrm{p}$-value relative to group $\mathrm{x}$ timing interaction was analyzed to determine the variation of scores according to the groups. A p-value of $<0.05$ was considered statistically significant.

\section{RESULTS}

The progression of the patients' quality of life according to the variable return to work showed a statistically significant difference at the times evaluated for the Functional, Physical, Pain, Vitality, Social and Mental variables. No difference was found in the scores at the different times for the other variables. (Table 1)

For the patients who did not return to work, the progression was statistically significant for the Functional, Physical, Pain, Vitality and Social variables. (Table 2)

In the retired patients, the progression was statistically significant for all the quality of life domains, except for "General". (Table 3)

Table 4 shows the values of median, percentiles 25 and 75 of the quality scores at the study times according to return to work. A variation in the quality scores depending on return to work was noted for the variable Vitality.

Table 1. Median (percentiles 25 and 75) of the quality scores at the study times of patients who returned to work.

\begin{tabular}{|c|c|c|c|c|c|c|}
\hline \multirow{3}{*}{ Variables } & \multicolumn{5}{|c|}{ Times } & \multirow{3}{*}{$\mathbf{p}$} \\
\hline & Pre & 1 month & 6 months & 1 year & 2 years & \\
\hline & \multicolumn{5}{|c|}{ Median (p25-p75) } & \\
\hline \multicolumn{7}{|l|}{ SF36 } \\
\hline Functional & $15(10-25)$ & $20(15-40)$ & $40(25-55)$ & $45(35-65)$ & $45(30-65)$ & $<0.001$ \\
\hline Physical & $0(0-25)$ & $25(0-25)$ & $50(0-50)$ & $50(25-50)$ & $50(25-50)$ & 0.001 \\
\hline Pain & $30(20-50)$ & 60 (50-70) & $60(50-70)$ & $65(60-80)$ & $70(60-80)$ & $<0.001$ \\
\hline General & $60(40-70)$ & 60 (50-75) & $70(50-80)$ & $70(55-80)$ & $70(60-90)$ & 0.061 \\
\hline Vitality & $55(35-60)$ & 60 (55-70) & $67.5(55-75)$ & $70(60-80)$ & $70(65-80)$ & $<0.001$ \\
\hline Social & $\begin{array}{c}50 \\
(37.5-75)\end{array}$ & $\begin{array}{c}75 \\
(62.5-87.5)\end{array}$ & $\begin{array}{c}81.3 \\
(62.5-87.5)\end{array}$ & $\begin{array}{c}87.5 \\
(75-87.5)\end{array}$ & $\begin{array}{c}87.5 \\
(75-100)\end{array}$ & $<0.001$ \\
\hline Emotional & $\begin{array}{c}33.3 \\
(0-100)\end{array}$ & $\begin{array}{c}100 \\
(0-100)\end{array}$ & $\begin{array}{c}100 \\
(66.7-100)\end{array}$ & $\begin{array}{c}100 \\
(100-100)\end{array}$ & $\begin{array}{c}100 \\
(66.7-100)\end{array}$ & 0.054 \\
\hline Mental & 60 (36-76) & $68(52-80)$ & $70(56-80)$ & $76(60-84)$ & $76(68-80)$ & 0.012 \\
\hline
\end{tabular}

Table 2. Median (percentiles 25 and 75) of the quality scores at the study times of patients who DID NOT return to work

\begin{tabular}{|c|c|c|c|c|c|c|}
\hline \multirow{3}{*}{ Variables } & \multicolumn{5}{|c|}{ Times } & \multirow{3}{*}{$\mathbf{p}$} \\
\hline & Pre & 1 month & 6 months & 1 year & 2 years & \\
\hline & \multicolumn{5}{|c|}{ Median (p25-p75) } & \\
\hline \multicolumn{7}{|l|}{ SF36 } \\
\hline Functional & $10(5-30)$ & $15(10-25)$ & $40(25-50)$ & $45(35-60)$ & $45(30-60)$ & $<0.001$ \\
\hline Physical & $25(0-25)$ & $25(0-50)$ & $25(0-50)$ & $25(0-50)$ & $50(25-75)$ & 0.039 \\
\hline Pain & $20(20-30)$ & $60(50-60)$ & $60(50-70)$ & $60(30-70)$ & $60(50-70)$ & 0.003 \\
\hline General & $65(50-80)$ & 75 (55-85) & 70 (55-80) & 75 (65-80) & $70(50-80)$ & 0.341 \\
\hline Vitality & $50(35-65)$ & $65(60-75)$ & $65(55-70)$ & $65(50-75)$ & $70(60-80)$ & 0.029 \\
\hline Social & $\begin{array}{c}50 \\
(37.5-62.5)\end{array}$ & $\begin{array}{c}62.5 \\
(50-75)\end{array}$ & $\begin{array}{c}87.5 \\
(62.5-87.5)\end{array}$ & $\begin{array}{c}75 \\
(62.5-87.5)\end{array}$ & $\begin{array}{c}75 \\
(75-87.5)\end{array}$ & 0.003 \\
\hline Emotional & $\begin{array}{c}33,3 \\
(0-66.7)\end{array}$ & $\begin{array}{c}100 \\
(66.7-100)\end{array}$ & $\begin{array}{c}100 \\
(66.7-100)\end{array}$ & $\begin{array}{c}100 \\
(66.7-100)\end{array}$ & $\begin{array}{c}100 \\
(66.7-100)\end{array}$ & 0.062 \\
\hline Mental & 56 (44-68) & 72 (64-80) & $76(56-80)$ & $68(52-80)$ & 68 (60-84) & 0.091 \\
\hline
\end{tabular}


Table 3. Median (percentiles 25 and 75 ) of the quality scores at the study times of retired patients.

\begin{tabular}{|c|c|c|c|c|c|c|}
\hline \multirow{3}{*}{ Variables } & \multicolumn{5}{|c|}{ Times } & \multirow{3}{*}{$\mathbf{P}$} \\
\hline & Pre & 1 month & 6 months & 1 year & 2 years & \\
\hline & \multicolumn{5}{|c|}{ Median (p25-p75) } & \\
\hline \multicolumn{7}{|l|}{ SF36 } \\
\hline Functional & $12.5(0-25)$ & $20(15-35)$ & $40(25-50)$ & $40(35-50)$ & $45(35-60)$ & $<0.001$ \\
\hline Physical & $0(0-25)$ & $25(0-50)$ & $25(0-50)$ & $25(25-60)$ & $37.5(25-60)$ & 0.001 \\
\hline Pain & $20(10-30)$ & $50(40-70)$ & $60(50-70)$ & $60(50-70)$ & $60(50-70)$ & $<0.001$ \\
\hline General & $60(45-70)$ & $70(60-80)$ & $70(60-80)$ & $65(60-80)$ & $62.5(55-80)$ & 0.187 \\
\hline Vitality & $55(40-65)$ & $60(50-75)$ & $67.5(55-75)$ & $70(60-80)$ & $70(65-80)$ & 0.004 \\
\hline Social & $\begin{array}{c}62.5 \\
(50-75)\end{array}$ & $\begin{array}{c}75 \\
(50-87.5)\end{array}$ & $\begin{array}{c}75 \\
(62.5-87.5)\end{array}$ & $\begin{array}{c}75 \\
(62.5-87.5)\end{array}$ & $\begin{array}{c}87.5 \\
(62.5-87.5)\end{array}$ & 0.017 \\
\hline Emotional & $\begin{array}{c}0 \\
(0-100)\end{array}$ & $\begin{array}{c}100 \\
(66.7-100)\end{array}$ & $\begin{array}{c}100 \\
(66.7-100)\end{array}$ & $\begin{array}{c}100 \\
(66.7-100)\end{array}$ & $\begin{array}{c}100 \\
(67.5-100)\end{array}$ & 0.022 \\
\hline Mental & $60(52-72)$ & $74(64-80)$ & $76(64-80)$ & $76(64-80)$ & $74(64-80)$ & 0.036 \\
\hline
\end{tabular}

\section{DISCUSSION}

The evaluation of the groups of patients in terms of return to activities produced results according to the SF-36 questionnaire applied at Hospital Estadual Mário Covas. The individual analysis of data was equated to the temporal variable of improvement.

For the functional variables relating to the quantification of physical effort, the groups of patients who returned to work, those who did not return, and retirees showed a significant improvement in scores, indicating that the patients are more fit to return to work. Other studies presented similar results when patients receiving social welfare benefits were compared with those not receiving benefits. ${ }^{16}$

Corroborating this discovery, the variables physical condition and vitality also appeared significant, a condition that is essential for improvement upon return to activity.

Relating the progress of pain, the main complaint made by the individuals, there was a statistically significant improvement in the evaluation performed in the first postoperative month. Over the course of the evaluations, the scores remained the same. Although pain was not completely absent, it did not restrict activities but remained at a tolerable level. In comparative studies of quality of life among patients in different work situations, similar results were observed for improvement of pain in the short and medium terms. ${ }^{17}$

With the improvement in pain and ability to perform activities requiring physical effort, the social variable of the patients was statistically significant, demonstrating that social interaction was resumed. On the other hand, the emotional evaluation, according to the test applied, did not show a significant difference between those who did and those who did not return to activities, being emotionally stable. In the group of retired subjects, there was a difference that may be related to age or disability, which may have led to unfitness for work. Epidemiological studies show that elderly patients with a history of vertebral disease are considered risk factors for pain and permanent disability, ${ }^{18,19}$ thus supporting the results obtained in our study.

In relation to the variable "mental", statistical significance was observed between the patients who returned to work, and those who retired, as the patients who did not return to work maintained the same score. Studies on the progress and prognosis of patients with low back pain show that patients with psychosocial disorders and high levels of stress usually have worse results. ${ }^{19}$ These variables were not taken into account in our study.

There was no significant p-value in the general item, as the patients were intellectually capable of social interaction, regardless of whether or not they were experiencing any state of depression, as these items were not evaluated.
Table 4. Median, percentiles 25 and 75 of the variables that evaluate quality of life of patients at the five study times according to return to work.

\begin{tabular}{|c|c|c|c|c|c|c|}
\hline \multirow{3}{*}{ Disease } & \multicolumn{5}{|c|}{ Time } & \multirow{3}{*}{${ }^{*} p$} \\
\hline & Pre & 1 month & 6 months & 1 year & 2 years & \\
\hline & \multicolumn{5}{|c|}{ Median (p25-p75) } & \\
\hline & \multicolumn{5}{|c|}{ SF 36 Functional } & \\
\hline Yes & $15(10-25)$ & $20(15-40)$ & $40(25-55)$ & $45(35-65)$ & $45(30-65)$ & \multirow{3}{*}{0.526} \\
\hline No & $10(5-30)$ & $15(10-25)$ & $40(25-50)$ & $45(35-60)$ & $45(30-60)$ & \\
\hline \multirow[t]{2}{*}{ Retired } & $12.5(0-25)$ & $20(15-35)$ & $40(25-50)$ & $40(35-50)$ & $45(35-60)$ & \\
\hline & \multicolumn{5}{|c|}{ SF36 Physical } & \\
\hline Yes & $0(0-25)$ & $25(0-25)$ & $50(0-50)$ & $50(25-50)$ & $50(25-50)$ & \multirow{3}{*}{0.974} \\
\hline No & $25(0-25)$ & $25(0-50)$ & $25(0-50)$ & $25(0-50)$ & $50(25-75)$ & \\
\hline \multirow[t]{2}{*}{ Retired } & $0(0-25)$ & $25(0-50)$ & $25(0-50)$ & $25(25-60)$ & $37.5(25-60)$ & \\
\hline & \multicolumn{5}{|c|}{ SF36 Pain } & \\
\hline Yes & $30(20-50)$ & $60(50-70)$ & $60(50-70)$ & $65(60-80)$ & $70(60-80)$ & \multirow{3}{*}{0.198} \\
\hline No & $20(20-30)$ & $60(50-60)$ & $60(50-70)$ & $60(30-70)$ & $60(50-70)$ & \\
\hline \multirow[t]{2}{*}{ Retired } & $20(10-30)$ & $50(40-70)$ & $60(50-70)$ & $60(50-70)$ & $60(50-70)$ & \\
\hline & \multicolumn{5}{|c|}{ SF36 General } & \\
\hline Yes & $60(40-70)$ & $60(50-75)$ & $70(50-80)$ & $70(55-80)$ & $70(60-90)$ & \multirow{3}{*}{0.330} \\
\hline No & $65(50-80)$ & $75(55-85)$ & $70(55-80)$ & $75(65-80)$ & $70(50-80)$ & \\
\hline \multirow[t]{2}{*}{ Retired } & $60(45-70)$ & $70(60-80)$ & $70(60-80)$ & $65(60-80)$ & $62.5(55-80)$ & \\
\hline & \multicolumn{5}{|c|}{ Vitality } & \\
\hline Yes & $55(35-60)$ & $60(55-70)$ & $67.5(55-75)$ & $70(60-80)$ & $70(65-80)$ & \multirow{3}{*}{0.028} \\
\hline No & $50(35-65)$ & $65(60-75)$ & $65(55-70)$ & $65(50-75)$ & $70(60-80)$ & \\
\hline \multirow[t]{2}{*}{ Retired } & $55(40-65)$ & $60(50-75)$ & $67.5(55-75)$ & $70(60-80)$ & $70(65-80)$ & \\
\hline & \multicolumn{5}{|c|}{ SF 36 Social } & \\
\hline Yes & $\begin{array}{c}50 \\
(37.5-75)\end{array}$ & $\begin{array}{c}75 \\
(62.5-87.5)\end{array}$ & $\begin{array}{c}81.3 \\
(62.5-87.5)\end{array}$ & $\begin{array}{c}87.5 \\
(75-87.5)\end{array}$ & $\begin{array}{c}87.5 \\
(75-100)\end{array}$ & \multirow{3}{*}{0.175} \\
\hline No & $\begin{array}{c}50 \\
(37.5-62.5)\end{array}$ & $\begin{array}{c}62,5 \\
(50-75)\end{array}$ & $\begin{array}{c}87.5 \\
(62.5-87.5)\end{array}$ & $\begin{array}{c}75 \\
(62.5-87.5)\end{array}$ & $\begin{array}{c}75 \\
(75-87.5)\end{array}$ & \\
\hline \multirow[t]{2}{*}{ Retired } & $\begin{array}{c}62.5 \\
(50-75)\end{array}$ & $\begin{array}{c}75 \\
(50-87.5)\end{array}$ & $\begin{array}{c}75 \\
(62.5-87.5)\end{array}$ & $\begin{array}{c}75 \\
(62.5-87.5)\end{array}$ & $\begin{array}{c}87,5 \\
(62.5-87.5)\end{array}$ & \\
\hline & \multicolumn{5}{|c|}{ SF 36 Emotional } & \\
\hline Yes & $\begin{array}{c}33.3 \\
(0-100)\end{array}$ & $\begin{array}{c}100 \\
(0-100)\end{array}$ & $\begin{array}{c}100 \\
(66.7-100)\end{array}$ & $\begin{array}{c}100 \\
(100-100)\end{array}$ & $\begin{array}{c}100 \\
(66.7-100)\end{array}$ & \multirow{3}{*}{0.637} \\
\hline No & $\begin{array}{c}33.3 \\
(0-66.7)\end{array}$ & $\begin{array}{c}100 \\
(66.7-100)\end{array}$ & $\begin{array}{c}100 \\
(66.7-100)\end{array}$ & $\begin{array}{c}100 \\
(66.7-100)\end{array}$ & $\begin{array}{c}100 \\
(66.7-100)\end{array}$ & \\
\hline \multirow[t]{2}{*}{ Retired } & $\begin{array}{c}0 \\
(0-100)\end{array}$ & $\begin{array}{c}100 \\
(66.7-100)\end{array}$ & $\begin{array}{c}100 \\
(66.7-100)\end{array}$ & $\begin{array}{c}100 \\
(66.7-100)\end{array}$ & $\begin{array}{c}100 \\
(67.5-100)\end{array}$ & \\
\hline & \multicolumn{5}{|c|}{ SF 36 Mental } & \\
\hline Yes & $60(36-76)$ & $68(52-80)$ & $70(56-80)$ & $76(60-84)$ & $76(68-80)$ & \multirow{3}{*}{0.119} \\
\hline No & 56 (44-68) & $72(64-80)$ & $76(56-80)$ & $68(52-80)$ & $68(60-84)$ & \\
\hline Retired & $60(52-72)$ & $74(64-80)$ & $76(64-80)$ & 76 (64-80) & 74 (64-80) & \\
\hline
\end{tabular}

*relative to group/time interaction obtained from Anova 
When the return to work groups were compared in the different periods of the trial, there was a statistical difference only for the variable vitality, as patients who did not resume work had a balanced average score, without presenting progression.

\section{CONCLUSION}

In spite of the different work situations, there was an improvement in quality of life in the different aspects evaluated in all the groups in the postoperative period, with more significant results observed in the group that returned to work, followed by the group of retirees, showing that the resolution or lessening of pain was essential for the improvement in quality of life.

All authors declare no potential conflict of interest concerning this article.

\section{REFERENCES}

1. Beurskens AJ, de Vet HC, Köke AJ, van der Heijden GJ, Knipschild PG. Measuring the functional status of patients with low back pain. Assessment of the quality of four disease-specific questionnaires. Spine (Phila Pa 1976). 1995;20(9):1017-28.

2. Fransen $M$, Woodward M, Norton R, Coggan $C$, Dawe M, Sheridan N. Risk factors associated with the transition from acute to chronic occupational back pain. Spine (Phila Pa 1976). 2002;27(1):92-8

3. Hoogendoorn WE, van Poppel MN, Bongers PM, Koes BW, Bouter LM. Physical load during work and leisure time as risk factors for back pain. Scand J Work Environ Health. 1999;25(5):387-403.

4. Loney PL, Stratford PW. The prevalence of low back pain in adults: a methodological review of the literature. Phys Ther. 1999;79(4):384-96.

5. Santos KGLL, Silva MAG. A prevalência de lombalgia em mulheres praticantes de ginástica em academias esportivas. Fisioter. 2003:4:117-25.

6. United States Government Accounting Office. Social security: disability programs lag in promoting return to work. Gaithersburg, MD: US Government Printing Office; 1996. (GAO/HEHS 97-46).

7. Buchbinder $R$, Jolley $D$, Wyatt $M$. Breaking the back of back pain. Med J Aust. 2001:175(9):456-7.

8. Marras WS. Occupational low back disorder causation and control. Ergonomics. 2000;43(7):880-902.

9. Andersson GB. Epidemiological features of chronic low-back pain. Lancet. 1999;354(9178):581-5

10. Iguti AM, Hoehne EL. Lombalgias e trabalho. Rev Bras Saúde Ocup. 2003,28:78-87.
11. Weiner DK, Sakamoto $S$, Perera $S$, Breuer $P$ Chronic low back pain in older adults: prevalence, reliability, and validity of physical examination findings. J Am Geriatr Soc. 2006;54(1):11-20.

12. de Goumoëns P, Schizas C, So AK. Low back pain in 2006: back to the root. Rev Med Suisse. 2006;2(65):1268-70.

13. DeBerard MS, LaCaille RA, Spielmans G, Colledge A, Parlin MA. Outcomes and presurgery correlates of lumbar discectomy in Utah Workers' Compensation patients. Spine J. 2009:9(3):193-203.

14. Atlas SJ, Tosteson TD, Blood EA, Skinner JS, Pransky GS, Weinstein JN. The impact of workers' compensation on outcomes of surgical and nonoperative therapy for patients with a lumbar disc herniation: SPORT. Spine (Phila Pa 1976). 2010:35(1):89-97.

15. Gallagher RM, Williams RA, Skelly J, Haugh LD, Rauh V, Milhous R, et al. Workers' Compensation and return-to-work in low back pain. Pain. 1995;61(2):299-307.

16. Mayer T, McMahon MJ, Gatchel RJ, Sparks B, Wright A, Pegues P. Socioeconomic outcomes of combined spine surgery and functional restoration in workers'compensation spinal disorders with matched controls. Spine (Phila Pa 1976). 1998;23(5):598-605.

17. McHorney CA, Ware JE Jr, Lu JF, Sherbourne CD. The MOS 36-item Short-Form Health Survey (SF-36): III. Tests of data quality, scaling assumptions, and reliability across diverse patient groups. Med Care. 1994:32(1):40-66.

18. Cassidy JD, Côté P, Carroll LJ, Kristman V. Incidence and course of low back pain episodes in the general population. Spine (Phila Pa 1976). 2005;30(24):2817-23.

19. Grotle M, Brox JI, Veierød MB, Glomsrød B, Lønn JH, Vøllestad NK. Clinical course and prognostic factors in acute low back pain: patients consulting primary care for the first time. Spine (Phila Pa 1976). 2005;30(8):976-82. 